\title{
MEDICAL COLLECTIONS IN TARTU OLD ANATOMICAL THEATRE - FROM AUGUST RAUBER'S ANATOMY MUSEUM TO A MULTIFUNCTIONAL RESEARCH AND EDUTAINMENT CENTRE
}

\author{
Maie Toomsalu, Andres Arend \\ Department of Anatomy, University of Tartu, Estonia
}

In 1890 Professor of Anatomy August Antonius Rauber founded a museum of anatomy at the Old Anatomical Theatre in Tartu (Dorpat) in order to illustrate his lectures and to improve the students' knowledge. As Rauber lectured in German whereas most of the students were Russians, illustrating lectures with models and original specimens was of great significance. Rauber himself was very skilful at anatomical preparation and he also trained the preparator Aleksander Reinvald who was of Estonian ethnicity. He writes, "Seitdem führt dieser Studiensaal ein fröhliches, nie unterbrochenes Dasein, hat sich in der Studentenschaft fest eingebürgert und wird voraussichtlich in Zukunft nicht wieder von der Bildfläche verschwinden" (Rauber, 1895) (Since then, the lecture hall is uninterruptedly teeming with happy life; it has found its rightful place among the students and, in all likelihood, will not disappear from the scene in the future). Rauber considered the museum most essential for the training of medical students and wrote about it in 1895: "Even the first impression of the hall is of significant educational value for the young medical student. It can be very well compared with the influence of the art museum on a young susceptible soul, which exceeds a certain limit where the scientific influence of the exhibits prevails. The first impression is festive and majestic, much more powerful than what a first-year student expects to see at the Anatomical Theatre. Thus, even the unexpectedness of the sight exerts a favourable influence. Many of them are so overwhelmed by the richness of the material that a certain amount of time is needed until an understanding is reached. Thus, the first impression is of great value for the entrant and 
makes an excellent beginning. During the semesters of clinical studies the student will experience the infinite practical value of anatomy. .... The painfully acquired anatomical knowledge will fade too quickly or disappear completely if one does not constantly work on its consolidation. Here, the museum of anatomy offers an excellent opportunity for avoiding such a danger" (Rauber, 1895). In the afternoons, after lectures, the exhibition was open for students of other faculties and townspeople. On Fridays, the exhibition was visited by housewives.

In his 1895 publication Über die Einrichtung von Studiensälen in anatomischen Instituten, Professor Rauber emphasized that people from other fields should visit the collections. "The exhibition hall which entirely lacks the frightening aspect is appropriate for students of other faculties for acquiring knowledge about their bodies through visualized teaching. If such an exhibition hall is able to exert its positive influence outside the Faculty of Medicine and encourage non-medics to study anatomy, it is, in my opinion, a sufficiently great achievement to justify their foundation at the institutes of anatomy in the future" (Rauber, 1895).

Unfortunately, a great number of exhibits of Rauber's museum, although not all of them, have been lost in the turmoil of wars. In September 2005, a medical exhibition was opened in the same Old Anatomical Theatre again, now under the name of the Medical Collections of the Faculty of Medicine of the University of Tartu. The exhibits include those that have survived from the time of Prof. August Rauber's museum. Some of them have been described in his famous textbook Lehrbuch der Anatomie des Menschen. The major part of the collection consists of exhibits on pathological anatomy: dissection and operation materials classified according to organ systems, wallcharts and wax moulages, numerous pathological bone specimens and skulls. The embryology collection shows specimens of normal development of human and animal foetuses but also malformations and wax models. The collection of the Estonian neurosurgeon Ludvig Puusepp (18991942) who worked in Russia before 1920 demonstrates several specimens of brains in fluid. The pharmacological display introduces scientists from Rudolf Buchheim (1820-1879), who in 1846 founded the first experimental laboratory of pharmacology in the world, to Lembit Allikmets (1936-) who was a long-time dean of the Medical Faculty, is an honorary citizen of Tartu and has done a lot for the 
development of medicine in Tartu. The collection of forensic medical specimens demonstrates different specimens related to intoxication, accidents, murder and suicide. The radiology collection demonstrates Xray equipment from different periods and also has a radiograph of hand from year 1896. Even Professor August Antonius Rauber himself is present again - his full-size wax figure is sitting behind his own writingdesk.

Usually different collections as memory institutions collect items that have lost their original function. The case is different, however, with the medical collections of the University of Tartu. With every information poster and specimen, the display reminds every interested visitor of the great contribution that the scientists who have worked at the Old Anatomical Theatre and collected and produced these specimens have made to Estonian as well as world science. A medical professional from every corner of the world is familiar with eponyms such as Burdach bundle (fasciculus cuneatus - cuneate fasciculus), Boettcher cells (epitheliocytus glandularis externus basalis), Kupffer cells (macrophagocytus stellatus), Rathke's pouch (saccus hypophysialis), Rathke's bundles (trabeculae carneae), Reichert's cartilage, Reichert's recess (recessus cochlearis), Volkmann's canal (canalis transversus, canalis perforans), Thoma ampulls, Hueck's ligament (ligamentum pectinatum anguli iridocornealis), Rauber's hepatic cord (a. hepatica propria), Rauber's layer, Rauber's ligament (ligamentum atlantoaxiale accessories), Reissner's membrane (membrana vestibularis), Reissner's duct (ductus cochlearis), Pirogov's triangle (trigonum linguale), Waldeyer's-Pirogov tonsillar ring, Bidder's organ, Bidder's knot, etc. They come and feel thankful towards these men. They are also grateful that such a collection has been preserved and that old specimens have not been destroyed or thrown away in shifting political and academic winds.

Medical exhibits, however, have retained their original function they contribute to the enrichment of knowledge of medical students. As a new function, the specimens of medical collections have become objects for international comparative biomedical studies. For example, when researching for her doctoral thesis Identifikation von Mutationen im Tumorsuppressorgen p53 und des Bakteriums Helicobacter pylori in Magenkarzinomen histopathologischer Präparate aus verschiedenen medizinhistorischen Sammlungen in 2011, Dr. Katharina Licht from 
Georg-August-University of Göttingen also used samples of gastric cancer from the Medical Collections of the University of Tartu, and as a result of her study she concluded that both, the changes of the mutation spectrum as well as of the localization of the mutations, indicate that the influences on the development of gastric carcinomas have changed during the last century. In addition to the large number of old specimens of different pathologies the Medical Collection in the Old Anatomical Theatre in Tartu also have unique exhibits of diseases which are rare nowadays or exhibits of terminal conditions of diseases which are not allowed to progress to that state in modern societies.

For practising doctors, the museum is a place for refreshing their memory and comparing symptoms. The museum has also acquired a number of new functions. The same exhibition is used to playfully teach very young children (of the $4^{\text {th }}$ school year) to know their anatomy and physiology. The exhibition has become a part of the education system through which school students and adults learn about the hazards of risk behaviour (smoking, overconsumption of alcohol, drug addiction, unsafe sex, wrong nutrition, etc.). Attempts are made to get schoolchildren interested in biology and medicine, which has caused great competition among those who would like to take up studies of medicine at the university. The medical exhibition has also become a place for selfreflection where adherents of a healthy way of life from the whole world get assurance that their behaviour is correct. As the feedback questionnaires and interviews with visitors show, in many cases the exhibition makes those who practise risk behaviour seriously reconsider their lifestyle and can provide impetus for changing their lifestyle and prolonging their lifespan. The exhibition has also been well received by disabled people as it gives them strength to cope with their lives. Specimens, models and posters tell the story of study and discovery of the human organism that has been increasingly dependent on the development of technology. The exhibits have been of great interest for children and adult artists, and their pictures inspired by the exhibition have been of great interest for visitors.

In conclusion, we can say that in the $21^{\text {st }}$ century the study hall that initially was meant to illustrate lectures has become a multifunctional place of edutainment. It has become a place where families and children spend their free time; school and university students study; doctors recall the time of their studies and revise what they have learned. 
Researchers study specimens of diseases. The collections have become a place where the exhibits influence people's emotions, giving them confidence or inspiring them to make changes in their lives.

The authors are of the opinion that the collections should retain all of their present functions because each specimen is special and different. Dividing the collections up into separate parts and displaying them at different places would destroy the wholeness of the exhibition and jeopardize the preservation of many rare specimens for the visitors.

Address for correspondence:

Maie Toomsalu

Institut of Anatomy

Medical Collections

Lossi 38, 51003 Tartu

E-mail: maie.toomsalu@ut.ee 